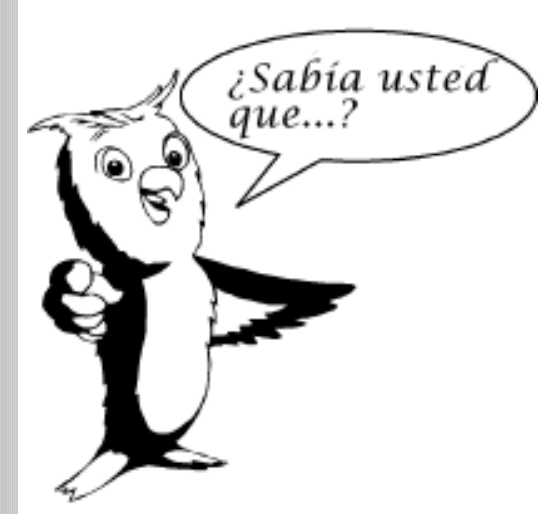

\title{
¿Hacia dónde va la Educación Médica? Reflexiones marginales al Congreso de la AMEE 2005 en Amsterdam
}

\author{
Profesor Andrzej Wojtczak MD., PhD
}

\section{Where is Medical Education going? Thoughts on a margin of AMEE Amsterdam Conference 2005}

No hay duda de que la globalización de la educación médica se ha convertido en un tema que atrae la atención de participantes de todo el mundo en casi todos los congresos. También es evidente que la AMEE (acrónimo inglés de la Asociación Europea de Educación Médica) se ha establecido firmemente como un líder incuestionable de la educación médica internacional y se ha transformado en un forum global para la innovación e investigación en educación médica. Sin embargo el término "educación médica internacional" conlleva algunas ambigüedades. Muchas facultades de medicina y organizaciones profesionales usan la palabra "internacional" simplemente como sinónimo de la palabra "extranjero" y se usa cuando los estudiantes extranjeros van a estudiar a un país determinado. El uso adecuado de este término se debería reservar para las situaciones en las que existe una unión de esfuerzos multinacionales, incluyendo las entradas y salidas de información, experiencias, conocimiento y experteza.

El Proceso de Bolonia cuyo objetivo, para el 2010, es el desarrollo de una Educación Superior Europea coherente y cohesionada, está captando la atención del sector educativo. No obstante, el Consejo de Ministros de Educación de la UE ha desatendido hasta ahora la educación médica. Ciertamente algunos de los retos son también de interés para los educadores médicos como por ejemplo la estructura curricular en dos ciclos (Grado y Master), o la cooperación en garantía de calidad, incluyendo el sistema europeo de acreditación y certificación.
No doubt that the globalization of medical education has become an issue that attracts attention of participants almost all conferences on medical education worldwide. It is also evident that AMEE has been firmly established as an unquestionable leader in international medical education and became a global forum for innovations in education and research. However, term "international medical education" faces some ambiguities. Many medical schools and professional organization are using the word "international" simply as proxy for the word "foreign" and uses in case when foreign students are coming to study in par-ticular country. A proper use of this term should be reserved to situations where the joint multinational efforts, which include inflows and outflows of information, experiences, knowledge and expertise, exist.

A great attention attracts the Bologna Process aiming at development of coherent and cohesive the European Higher Education by 2010. However, medical education has so far been neglected by the EU Committee of Ministers of Education. Some challenges such as two-cycle curriculum structure (Bachelor \& Master) or cooperation in quality assurance in-cluding European system of accreditation and certification are certainly of interest to medi-cal educators.

A great interest in the worldwide partnership of medical schools and institutions - the International Virtual Medical Schools (IVIMEDS) - that is deve-

1. Publicados en español en Educación Médica Volumen 7, Suplemento 2 (Julio-Septiembre 2004)

2. Publicados en español en Educación Médica Volumen 6, Suplemento 2 (Julio-Septiembre 2003) 
Los consumidores potenciales expresaron mucho interés por la asociación mundial de facultades de medicina e instituciones (International Virtual Medical Schools -IVIMEDS) que está desarrollando el material de aprendizaje en línea para todo el continuum de la educación médica.

Se expresó una preocupación bien fundamentada a la vista del incremento desmesurado del número de facultades de medicina mundiales y su comercialización. Esto supone un peligro real para la calidad de la educación médica ya que muchas de ellas se han establecido sin los recursos académicos, institucionales y financieros adecuados. Por lo tanto el tema de los estándares internacionales y la evaluación de la competencia profesional de los médicos se han convertido en un asunto "caliente". Dado que la medicina no es sólo una ciencia sino también una búsqueda cultural, es preciso desarrollar estándares a nivel internacional. Actualmente, la comunidad médica internacional se interesa por dos conjuntos de estándares para la educación médica global: la Trilogía de Estándares Globales de la WFME (acrónimo inglés de la Federación Mundial en Educación Médica) desarrollados para acreditación de facultades de medicina, y los Requisitos Globales Esenciales Mínimos, orientados a los resultados y definidos para evaluar las competencias requeridas de los licenciados y puesto a prueba en las ocho mejores facultades de medicina de China a través de un sistema de exámenes diseñado especialmente para la ocasión. Ambos conjuntos de estándares son complementarios y deberían ser útiles para proceso de evaluación de la calidad de las facultades de medicina y sus productos.

A base de escuchar muchas discusiones y presentaciones está claro que la educación médica está al borde de un gran cambio paradigmático: desde un enfoque basado en la estructura y el proceso hacia una educación basada en competencias y medición de los resultdos del proceso educativo. En mi opinión, este desarrollo dirigido a evaluar las competencias de los médicos, continuará siendo un reto durante la próxima década. Para concluir, me gustaría citar el credo educativo del Profesor Farmer (1988) que desearía que se convirtiera en el lema de todos los educadores médicos: "La excelencia en educación no ocurre de manera accidental; es el resultado de una búsqueda que requiere una planificación y ejecución cuidadosa y que no puede desarrollarse sin la debida atención. La cuestión de la excelencia no depende del dinero sino de las ideas, prioridades y energías invertidas por las personas implicadas." loping the e-learning mate-rial across the continuum of medical education was expressed by it potential customers.

A well founded concern, in view of an explosion of the number of medical schools world-wide and their commercialization, was expressed. It creates a real danger to the quality of medical education as many of them have been established without adequate academic, insti-tutional and financial resources. Therefore the issue of the international standards and as-sessment of professional competence of physicians became a hot topic. As medicine is not only scientific but also cultural pursuit it requires internationally developed standards. Pres-ently, two sets of global medical education standards have received interest by the interna-tional medical community, the WFME Trilogy of Global Standards developed for accredita-tion of medical schools, and the "Global Minimum Essential Requirements" (GMER) - out-come-oriented - defined to assess required competencies of graduates and tested in eight top-ranging Chinese medical schools in specially designed examination system. Both these developments are complementary and should well serve the process of evaluation of quality of medical schools and their products.

Listening to many discussions and presentations it is clear that the medical education is on the brink of a major paradigm shift from structure and process-based toward compe-tency-based education and measurement of outcomes of educational processes. In my opinion, this development aiming at assessment of physicians' competences will remain a challenge for coming decade. In conclusion, I would like to quote educational credo of Professor Farmer (1988) "Excellence in education does not occur accidentally, it is the result of a pursuit that requires careful planning and implementation, and it can not grow unattended. The question of excellence does not depend on money it depends on ideas, priorities and the focused energies of people" that I wish it would become the "motto" of all medical educators. 